\title{
Beyond the Books: Teacher Practices and Perceptions of Teaching Caring and Curiosity
}

\author{
Louis S. Nadelson ${ }^{1, *}$, Sandra G. Nadelson ${ }^{1}$, Ann Broyles ${ }^{1}$, Janet Edgar ${ }^{1}$, Jeryca Einhorn ${ }^{1}$, Annette Hatchett ${ }^{1}$, Tabitha \\ Scroggins ${ }^{1}$, Alicia Skipper ${ }^{1} \&$ Cara Ulrich $^{1}$ \\ ${ }^{1}$ Department of Leadership Studies, College of Education, University of Central Arkansas, Conway, AR, USA \\ *Correspondence: Department of Leadership Studies, University of Central Arkansas, Conway, AR 72035, USA. Tel: \\ 1-501-450-3254. E-mail: Inadelson1@uca.edu
}

Received: June 23, 2019

Accepted: August 12, 2019 Online Published: August 21, 2019

doi:10.5430/jct.v8n3p84

URL: https://doi.org/10.5430/jct.v8n3p84

\begin{abstract}
Caring and curiosity are fundamental to learning and working well with others. Individuals who are both caring and curious have empathetic curiosity and want to know about other people and take the initiative to learn about perspectives, needs, and goals of those around them. Empathetic curiosity can be enhanced through activities in schools. The goal of our project was to determine teachers' perceptions and practices associated with teaching and learning caring and curiosity. The data we collected from $183 \mathrm{~K}-12$ teachers revealed positive perceptions of teaching caring and curiosity. We found that the instructional methods used to teach caring shifted with the curricular content. Our research also revealed that the focus of curiosity changed when the teaching concentrated on content rather than the instruction method. The teachers relatively limited focus on caring for others when teaching caring suggests that they may not be considering empathetic curiosity as a learning goal. Based on our findings we interpret our results and provide implications for teaching and learning.
\end{abstract}

Keywords: caring, curiosity, dispositions, student, perceptions, empathy, teacher

\section{Introduction}

\subsection{Why Teach Caring and Curiosity}

The goal of education is to prepare students to be productive and supportive members of society. Therefore, it is important that educators attend to student development beyond the acquisition of content knowledge (McDermott, 2003, 2014). Greenberg and colleagues (2003) argue that students experience higher levels of achievement when they are prepared with a range of social and emotions skills and an array of dispositions. As our society becomes more diverse there is a need for citizens to have the skills and knowledge to bridge differences (Derman-Sparks, 1993; Phillips, 2015, 2016). Embracing diversity requires people to care about others and be curious about them - a combination that Phillips (2016) refers to as empathetic curiosity. Thus, to help prepare students to collaborate with others, be culturally competent, and to effective communicators, it is imperative that we prepare them to be both caring and curious.

There are several potential interventions for teaching students a range of social and emotional skills, including caring and other dispositions (e.g., Durlak, Weissberg, Dymnicki, Taylor, \& Schellinger, 2011). However, there is limited time for teachers to focus on developing character traits. In many schools, there is greater emphasis on academic skills and content. As a result, less time is devoted to helping students develop their social and emotional skills and capacity (Louis, Murphy, \& Smylie, 2016; McDermott, 2003; Orkin, 1996). With less attention to social-emotional development, such as caring and less attention toward dispositional development such as curiosity, students are less likely to develop as citizens who are prepared to be productive in school and society (McDermott, 2003).

Given the potential for many schools to have eliminated a specific curriculum or systemic approach to student development of caring and curiosity as part of a larger dispositional and social-emotional intervention and curriculum, there is more reliance on teachers to integrate the teaching of caring and curiosity through their instructional choices. Thus, there is an elevated potential for a wide variation in teacher perceptions and practices for 
teaching students to be more caring and curious, particularly about others. The need for students to be both caring and curious to thrive led us to wonder - what are teachers' thoughts about and practices related to teaching and learning caring and curiosity? The lack of current empirical research and the importance of the dispositions justifies our research.

\subsection{Caring in the Cuirriculum}

Blackwell (1999) suggests that teaching students to be kinder will improve everyone's quality of life. In some schools, the faculty and administration have adopted a curriculum that embeds teaching students to care for others as a set of lessons (e.g., Smith, Hurst, \& Skarbek, 2005). However, the emphasis on student performance on standardized tests has resulted in the teaching of caring and empathy to be superseded by a focus on academic content, until problem behaviors arise (Kohn, 2000). Extreme events such as school shootings, bullying, and teen suicides may influence the consideration and adoption of curriculum that embeds dispositional learning (Espelage, Mebane, \& Adams, 2004). Thus, under duress educators may consider shifts in instruction to increase student dispositional development such as modeling caring and kindness in anticipation that the students are likely to mimic the behaviors (Borowiec, 2002)

Caring in the curriculum has been given attention by educators such as Noddings (2005) who argues for caring and character development in schools. Although Noddings and others have written much about the importance of caring, there is a dearth of research on teacher perceptions and practices for integrating caring into the curriculum and the subsequent influence on student learning. We have found most related research projects have focused on the examination of incorporating social-emotional learning standards as the focus on pre-developed curricular plans (Durlak, Weissberg, Dymnicki, Taylor, \& Schellinger, 2011), with little attention toward investigating the choices and approaches teachers intentially consider and use to integrate the teaching of caring. In studies of caring curriculum implementation, we found the educators in some schools create daily routines and activities that integrate kindness and caring (Jones, Bailey, \& Jacob, 2014). For example, Wheeler (2005) reports on how the educators in one school implemented a "kindness jar" where students would write kind things that they witnessed and the integration of readings about kindness, which led to increased conversations about kindness. By having multiple discussions about kindness, the students learned how to respond to others with kindness with the anticipation that the focus on kindness would became part of their mindset (Wheeler, 2005).

While teachers can influence the caring development of their students by simply being a role more, the teachers could be more effective at teaching their student to be caring if they understand caring and how to foster caring growth in others (Narinasamy \& Logeswaran, 2015). Some teacher preparation programs have integrated content for preparing teachers to incorporate caring lessons into their lesson plans (Smith \& Gill Lopez, 2016). Smith and Gill Lopez (2016) investigated the outcome from assigning student teachers the task of creating lesson plans that integrated literacy standards and social-emotional learning standards. After observing the lessons and providing the student teachers critical feedback, Smith and Gill Lopez found that the student teachers were much more willing to embed social-emotional learning standards into their future lessons as teachers because of the benefits they saw from previous teachings. Further, evidence suggests that the teachers' behaviors and motivations increased their propensity for teaching caring, as the teachers' reflections were reflected in their students' actions.

Thus, there is evidence to suggest that when teachers include caring as part of the curriculum, they are more likely to continue to integrate caring content in their lessons. Also, evidence indicates that when teachers are prepared to teach caring they are more likely to integrate related content as part of the general curriculum. Therefore, there is justification for examining teachers' perceptions and practice for teaching caring.

\subsection{Curiosity in the Curriculum}

Curiosity in a complex construct that is difficult to define and assess, yet is essential for learning (Loewenstein, 1994). Curiosity is arguable a concept that should inherently be fostered across the curriculum; however, with an emphasis on state-mandated testing, there has been a diminished focus on curiosity and the teaching of curiosity is not often-enough thoughtfully and strategically embedded into the curriculum (Engel, 2011; Johnson, 2012). The typical approach of direct instruction may lead to successfully passing a selected-response test, but not to the development of deep epistemic curiosity that is essential for advances in science and innovation (Knodt, 2009; Lindholm, 2018). There are cases in which instructors have made attempts to foster student curiosity through instructional and content choices (Binson, 2009). While more schools are offering classes that encourage creative thought and innovative thinking like the Education Accelerated by Service \& Technology program (EAST Initiative, 2018), our interest is in how teachers plan for and teach curiosity as part of the general curriculum, and the focus of the curiosity in their general curriculum instruction. 
In our search of the literature, we found very few empirical reports on the effectiveness of teaching curiosity to students in a general education classroom as part of the general curriculum (Dyjur \& Li, 2010). Many of the reports we found were similar to Knodt's (2009) in which instructional methods are shared but lacked an empirical foundation for the influence of the intervention on student curiosity. Several of the reports detailed specific interventions and the influence on multiple dispositions (Foss, 2014). One of the few empirical reports we located detailed the outcome of teaching students to be curious took place in an English Language classroom (Gurning \& Siregar, 2017). In the study the students were split into groups to determine if a curiosity-based strategy was more effective for learning than an approach that required the students to interact less with the text. Gurning and Siregar (2017) found that students who were more curious were more successful and acknowledged that teaching curiosity is a necessary part of the curriculum. Curiosity is also thought to be fostered through inquiry projects in which students explore idea and attempt to answer personally generated questions (Zion \& Slezak, 2005).

While there are multiple options for teachers to incorporate teaching curiosity in the curricula, our interest is in how teachers teach curiosity and what igs the curiosity content that is being taught. Given the importance of curiosity for learning and working with diverse populations, there is justification for examining teachers' perceptions and practice associated with teaching curiosity.

\subsection{Connecting Caring and Curiosity}

There is an inextricable connection between caring and curiosity, resulting in empathetic curiosity (Philips, 2015, 2016). The term "curiosity" is linked to the Latin word "Curare," which means to take care of, suggesting an etymological foundation for the link between the terms care and curiosity. The connection between caring and curiosity is a critical consideration because without curiosity individuals would not have interest in other people, reducing the likelihood that they would put forth the effort to get to know and appreciate others, particularly people who may be perceived to be different than them (Baumgarten, 2001).

Being curious about other cultures and practices leads to learning and often, openness to diversity (Philips, 2016). We maintain that knowing about others is essential for developing friendships, engaging in collaborations, and effective communication. Thus, curiosity is at the root of connecting with others and caring about people (Philips, 2015). Being connected is essential to healthy humans (Brown, 2015), and caring and curiosity are both character strengths that we should be developing in our students (Park \& Peterson, 2009).

When parents, teachers, and caregivers show empathy and care, they are modeling an example for the young people who see them and learn from them (Cotton, 1992; Du, Buchanan, Hayhurst, \& Ruffman, 2019; Mesurado \& Richaud, 2017; Scott \& Graham, 2015; Wagers \& Kiel, 2019). Young children may become aware and, therefore, curious about how they can make a difference when they care and are empathic. For instance, when people care for others, they become easier to work with, are more productive, and are likely to be more inclusive of others who are not like them (Gerace, Day, Casey, \& Mohr, 2015; Kasl \& Yorks, 2016; Lindsey, King, Helb, \& Levine, 2015).

There is a link between prosocial qualities and academic success in children (Hyson \& Taylor, 2011). The relationship between curiosity and caring and student success provides justification for teaching both of the constructs across the curriculum. When children learn how to be compassionate and courteous of others from their teachers and caregivers, they may be inspired to apply their knowledge and skills and learn more about others. Empathy begins to come more naturally as people feel connected to the knowledge that they have acquired. The associate between caring, curiosity, and working with others provides justification for examining teachers' perceptions and practices for teaching their students to be caring and curious.

\subsection{Developing Students' Dispositions}

Dispositions are a mindset or way of thinking that influence attitudes, interactions with others, behaviors, and perceptions of situations (Katz, 1993). Dispositions begin to form early (Bertram \& Pascal, 2002) and are influenced through long-term interactions and experiences (Carr \& Claxton, 2002; Shum \& Crick, 2012). Thus, teaching students' dispositions is a long-term commitment that is likely to involve the collaboration among teachers, peers, and family members (Durlak, Dyrnicki, Taylor, Weissberg, \& Schellinger, 2011). In our search of the literature, we found very few empirical reports on the results of teaching children dispositions as part of the general curriculum. Most studies on disposition development focus on life skill development at the school level (Orkin, 1996), in special education (e.g. Cronin, 1996) or through specific programming, such as 4H (e.g. Luckey \& Nadelson, 2011) or programs such as Head Start (e.g. Deming, 2009). Thus, there is a need to examine how dispositions, such as being caring and curious, are taught being taught in the general curriculum.

Katz (1977) argues that children's dispositions are influenced by their school experiences. Thus, it is important that 
dispositions are taught in a meaningful and strategic manner to assure students are learning to be civil, caring, and respectful of others. Children are going to display dispositions they witness; therefore, it is critical that teachers act as role models for their students and display positive dispositions (Wentzel, 1997). When educators display curiosity and creativity and value the same dispositions in their students, they are likely to flourish in the classroom and help their students develop the dispositions (Patrick, Hisley, \& Kempler, 2000). Accordingly, educators can also be the cause of undermining children's dispositions if there are not provided with the opportunities for experiencing caring relationships and activities to develop curiosity (Neuman \& Roskos, 2005). Given the evidence that indicates that teachers tend to view their role differently based on the educational context (Ben-Peretz, Mendelson, \& Kron, 2003), there is a warrant for determining how educators perceive their role in supporting their students' development of positive dispositions.

\subsection{Perceptions of Teacher Responsibility}

Teachers potentially hold many responsibilities ranging from maintaining order in the classroom, providing instruction, and keeping records of student performance and behaviors. However, some teachers recognize that they also have the responsibility to help their students develop as citizens (Tuff, 2009). Henson (2001) found that some preservice teachers perceive it is their responsibility to engage in the moral development of their students actively. Thus, it is possible for teachers to perceive they are responsible to support student development of dispositions, attitudes, citizenship, and mindsets. Dispositions and attitudes could include caring and curiosity.

Students tend to believe that teachers must help create school classroom climates that emulate respect and caring (DeRoche \& Williams, 2001), which indicates an expectation that teachers are responsible for teaching students to be caring. Cloninger (2008) found that caring interactions between teachers and students create a conducive and meaningful learning environment, which again indicates teachers modeling caring influences student learning. However, the perceived levels of responsibility for teaching dispositions can be culturally influenced (Tomita, 1997). Thus, the levels to which teachers might assume responsibility for teaching dispositions may vary by the community or school culture and climate.

It is interesting to note that beyond helping young people develop as citizens when teachers engage in character education they tend to have higher levels of satisfaction with the profession (Kim, Harris, \& Pham, 2018). Given the potential benefits for teaching caring and curiosity (as dispositions) for students and teachers and the potential for teachers assuming responsibility for teaching the dispositions, there is justification for examining teacher perceptions of their responsibility for and engage in teaching caring and curiosity.

\section{Method}

\subsection{Research Question}

The overarching research question for our investigation was: What are teachers' perceptions and practices for teaching students and students learning to be caring and curious? We developed the following guiding research questions to frame our investigation:

- What are teachers' perceptions of students learning to be caring?

- What are teachers' perceptions of students learning to be curious?

- What practices do teachers use to teach their students to be caring?

- What practices do teachers use to teach their students to be curious?

- What is the relationship between the teachers' perceptions and practices for caring and curiosity teaching and learning?

- Are there differences in perceptions and practice based on the school type, location, or demographics?

\subsection{Participant Characteristics}

The K-12 teachers we recruited to participate in our research were from a southern region of the United States. The 183 educators who completed our survey had an average age of $41.03(S D=12.78)$ and had taught for an average of 11.93 years $(S D=9.91)$. One hundred fifty-five participants identified as female and 28 identified as male. Most of the teachers identified at Caucasian (72\%), 23\% identified as African American, 2\% as Native American, $2 \%$ as Hispanic and $1 \%$ responded with "other" as their ethnicity. The percentage of participants with their highest achieved degree as a bachelor degree was $46 \%$, with the next highest percentage being master degree at $39 \%$, about $5 \%$ indicated they had education specialist, a $4 \%$ had post-bachelor certificate, and $4 \%$ indicated "other" with $2 \%$ 
declining to respond. The highest percentage of participants were from suburban communities $(42 \%)$ followed by urban $(33 \%)$ and then rural (24\%). The largest percentage of teachers taught in elementary schools (38\%), $18 \%$ taught at the middle/junior high level, $12 \%$ in high schools, $12 \%$ in K-12 schools, $8 \%$ at the preschool level, $6 \%$ worked in K-8 schools, $5 \%$ worked in 6-12 level schools, and 1\% declined to respond. About $46 \%$ of the participants worked in public schools, $38 \%$ in charter schools, $15 \%$ in private schools, and $1 \%$ declined to respond.

\subsection{Survey Development}

The lack of research tools that could be used to measure perceptions and practices associated with teaching and learning caring and curiosity to students at the K-12 level led us to develop an instrument for our study. We began our instrument development with identifying aspects of Noddings (2013) caring work and Kashdan and colleagues (2018) five-dimension curiosity scale. Then, as a research team, discussed the importance of and processes for teaching and learning caring and curiosity. Our discussion included and exploration of perceptions of why or who should be responsible for teaching caring and curiosity to students and the approaches that may be effective for enhancing student caring and curiosity. We then developed a series of selected response Likert scale (or Likert like scale) items focused on perceptions and practices for teaching and learning caring and curiosity in schools. Through our item development process, we also developed over 40 of free response items.

Following our initial item development, we aligned the items with our study focus to assure we had a sufficient number of items to address each of our guiding research questions. We then eliminated some of our redundant or irrelevant items, added a few more items, and modified some items. The result of our development was four or five items aligned with teaching caring, teaching curiosity, learning caring and learning curiosity.

To establish the validity of our instrument we had seven K-12 educators take our survey and provide us with feedback. Specifically, we asked the educators to share with us their thoughts about how much the items were aligned with teacher perceptions and practice associated with teaching and learning caring and curiosity. Based on their feedback, we made minor modifications to form a final survey.

Our final survey contained several demographic items, three free response items, and 24 selected response items. Our free response item includes stems such as, "How do you encourage your students to be more curious?" and "How do you teach students to care for others?" Our selected response items included stems such as, "I do not think you can teach students to be caring" and "I teach my students to develop new strategies" which the participants responded to on a five-point Likert scale. The calculated reliability of our tool was a Cronbach's alpha of .71, indicating an acceptable level of internal consistency.

\subsection{Sampling and Data Collection}

All data collection took place online. Using a convenience sampling approach, we recruited participants for our research by distributing an invitation email to teachers in schools and districts where we had received permission to conduct our investigation. The email contained a brief description of our research and a link to our online survey. The emails were distributed to all potential participants, and one week later, we sent a reminder email. All data collected was anonymous, as we did not collect any personal identifiers.

\subsection{Analysis}

\subsubsection{Quantitative Data}

We began the analysis of our quantitative responses by conditioning our data, which included removing responses that were not at least $90 \%$ complete. We then used the replace missing values feature in SPSS to insert the series mean for the skipped items in our data set. We reverse coded all responses to the negatively phrased items. Once our data set was conditioned were aligned our quantitative items to the focus of our guiding research questions (e.g. perceived influence of tool use on student engagement) and calculated the average composite scores for the item groups.

\subsubsection{Qualitative Data}

For our qualitative data, we used the literature and conversation to identify a series of themes representative of the perceptions and practice for teaching and learning caring and curiosity. We then created a list of codes representative of the caring content themes (see Table 1), themes for practices for teaching caring (see Table 2), and themes representative of both content and practice for teaching curiosity (see Table 3 ). 
Table 1. Caring Themes and Representative Codes

\begin{tabular}{ll}
\hline Theme & Representative Code \\
\hline Caring for self (CS) & $\begin{array}{l}\text { Take responsibility, work ethic, good diet and exercise (wellness), independence, love and } \\
\text { belief in self, self-worth, life skills }\end{array}$ \\
Caring for others (CO) & Social skills/interactions, listening, cooperating, treat others with respect \\
Caring for all (CA) & Caring for self and for others, and respect, citizenship, collaboration \\
\hline
\end{tabular}

Table 2. Themes and Representative Codes for Practices for Teaching Caring

\begin{tabular}{ll}
\hline Theme & Representative Codes \\
\hline Role Model (RM) & Being an example, leading by doing \\
Dialog (D) & Discussion, debate, reflection, reading \\
Practice (P) & collaborating, service learning, volunteering, community service \\
Independent Exploration (IE) & Self-determined learning \\
\hline
\end{tabular}

Table 3. Themes and Representative Codes for Practices and Content for Teaching Curiosity

\begin{tabular}{ll}
\hline Theme & Code \\
\hline Joyous exploration (JE) & $\begin{array}{l}\text { Open to new experiences, personal growth, seek opportunities to learn and grow, positive } \\
\text { emotions toward learning, arts and crafts, exercise/athletics }\end{array}$ \\
& $\begin{array}{l}\text { Solve problems, think about abstract and complex ideas, dislike of the unknown, eliminate } \\
\text { knowledge gaps }\end{array}$ \\
Deprivation sensitivity (DS) & Low impact of doubt, low impact of confusion, willing to embrace inherent anxiety with \\
& new, unknown, novel situations \\
Stress tolerance (ST) & Other people thinking and doing, listening, social interactions \\
Social curiosity (SC) & Novel, complex intense experiences, take risks (sometime unhealthy), attention seeking \\
\hline
\end{tabular}

\subsubsection{Data Coding}

We began our coding process as a group with all team members contributing to the discussion of coding the first 15 qualitative responses. Following the group experience, two team members were assigned to code the same set of items independently. We formed four pairs of researchers, and each pair coded a subset of the data set. Once the independent coding was complete, the pairs of coders met and discussed their results, and through discussion, they came to a consensus in their codings. We provide additional details of the outcome of our analysis as we report our findings.

\section{Results}

\subsection{Perceptions of Learning to Be Caring}

Our first guiding research questions asked: What are teachers' perceptions of students learning to be caring? To answer this question, we examined the responses to our selected response items aligned with teaching and learning caring (see Figure 1). The results indicate the teachers tend to fall between disagree to strongly disagree $(M=1.68)$ to the idea that students cannot be taught to be caring, which indicates the teachers perceived that students can be taught to be caring. We found that the teachers were nearly neutral with their perceptions that students' levels of caring were influenced by their parents $(M=2.87)$. They also disagreed that the sole responsibility lies with parents to teach students to be caring $(M=2.22)$. The participants tended to agree that students' levels of learning about caring are influenced by their peers $(M=3.97)$. Our analysis revealed the teachers tending to agree that they get frustrated when they have students who do not care for others $(M=3.88)$. In summary, our findings suggest that teachers perceive students can be taught to be caring and teachers have some responsibility to help students learn to be caring. Our results also indicate that teachers perceive that students' levels of caring is influenced by their peers and parents. 


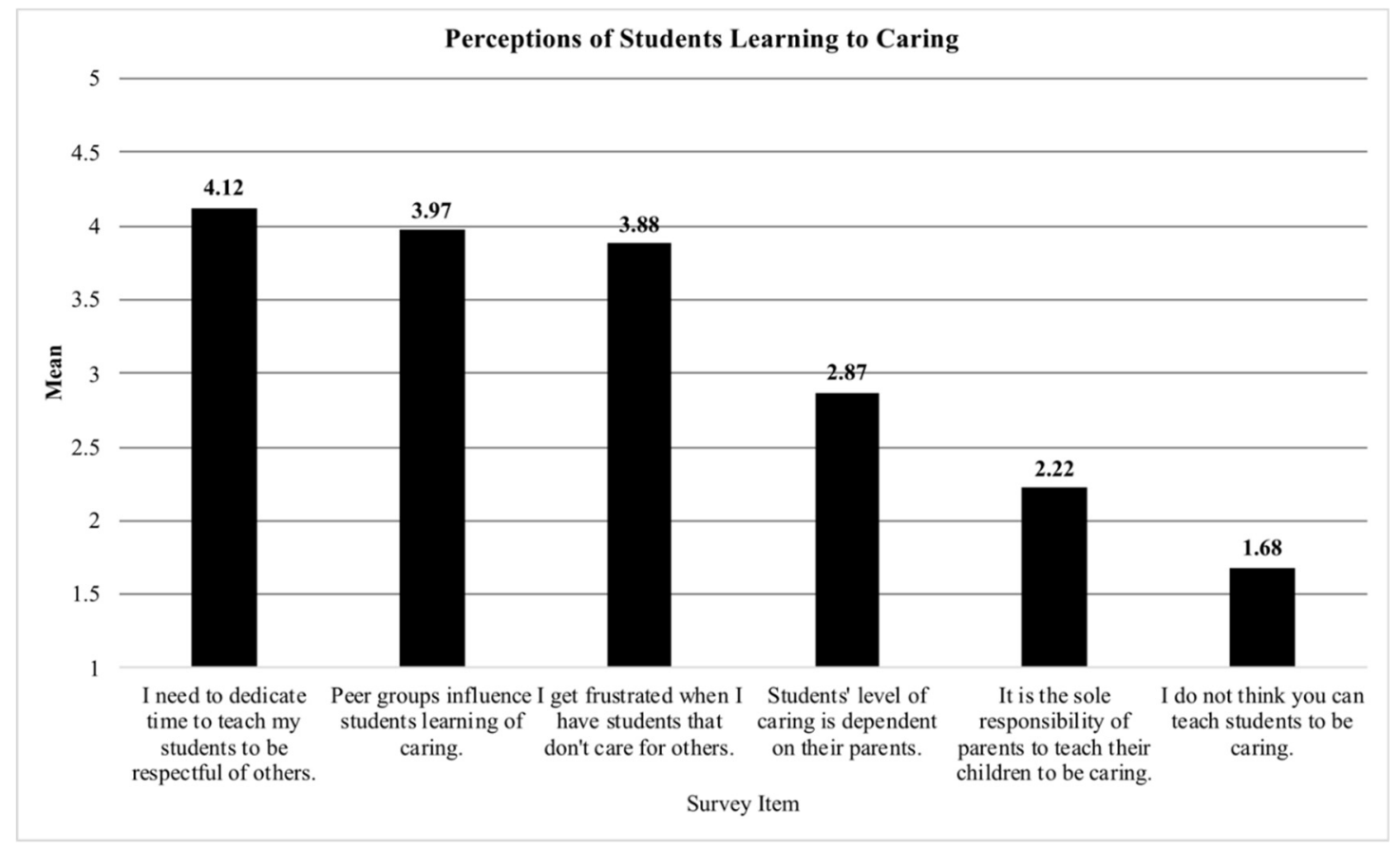

Figure 1. The Participants' Average Responses to Perceptions of Students Learning and Being Taught to Be Caring

\subsection{Perceptions of Learning to be Curious}

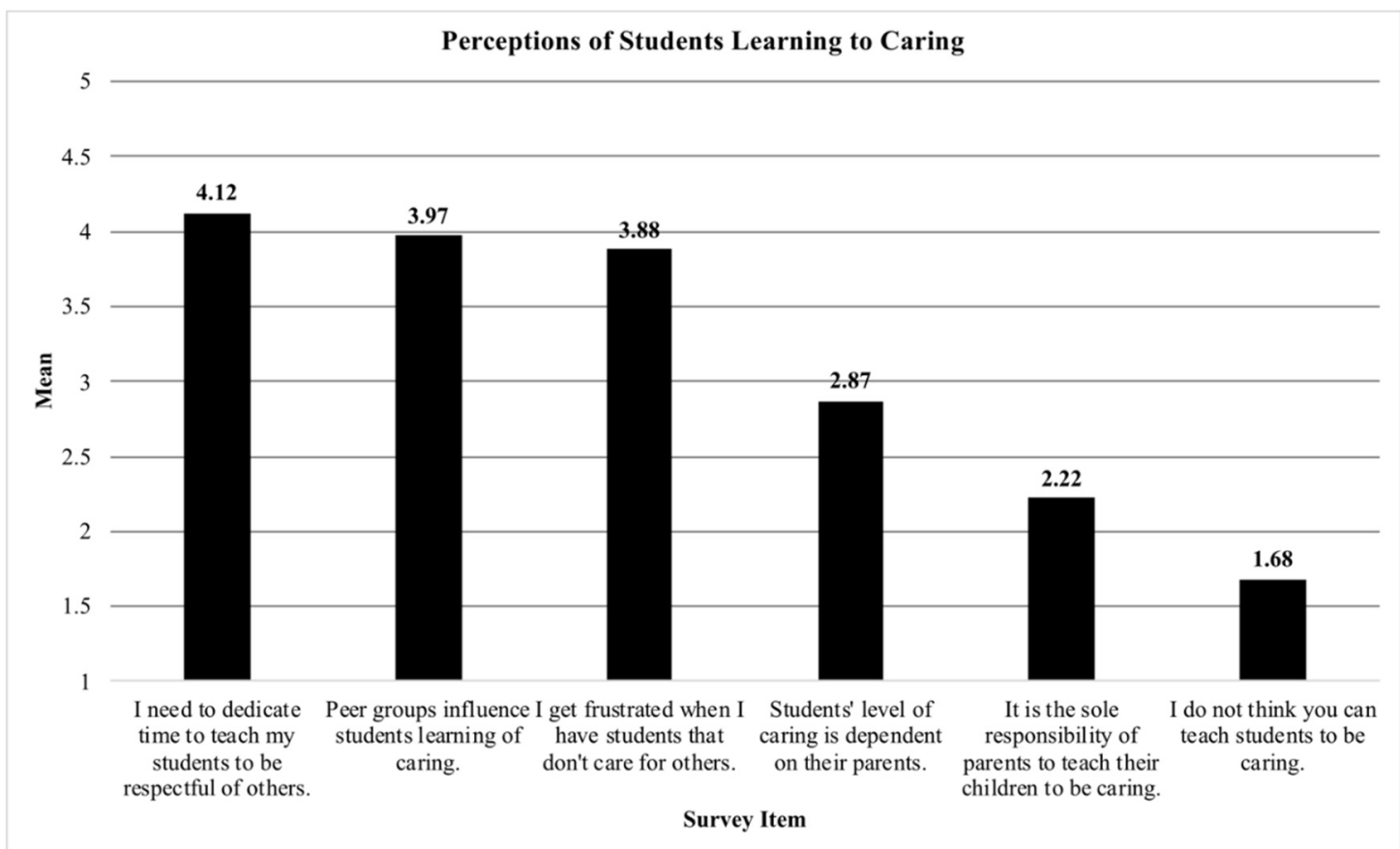

Figure 2. Teachers' Perceptions of Students Learning to be Curious and Influences on Students' Levels of Curiosity

Our second guiding research questions asked: What are teachers' perceptions of students learning to be curious? To answer this question, we examined the responses to our selected response items aligned with learning curiosity (see Figure 2). Our analysis revealed the teachers tending to disagree with the notion that individuals' curiosity is fixed $(M=1.78)$ and agreeing that students need support to learn to be curious $(M=4.10)$. The teachers were between 
disagree and neutral toward students getting less curious over time $(M=2.39)$ and tended to be near neutral in their perceptions of formal education decreasing students' curiosity over time $(M=2.72)$. The participants were near neutral in their perceptions of desk time diminishing levels of student curiosity $(M=3.09)$ and had similar perceptions of technology, making students more curious $(M=3.04)$. The participants trended toward agreeing with the idea that students who ask more questions are better learners $(M=3.35)$. Our results suggest the teachers perceive students can learn to be more curious, there may be conditions that are more conducive to helping the students learn to be more curious, and teaching students to be curious may enhance their curiosity.

\subsection{Teaching Caring}

Our third guiding research questions asked: What practices do teachers use to teach their students to be caring? To answer this question, we examined the responses to the corresponding selected response items (see Figure 3). We also examined the coded qualitative responses associated with teaching caring (see Table 4). Our analysis revealed that the participants tended to agree to strongly agree that they expect their students to be kind to others at all times $(M=4.54)$ and similarly agree to strongly agree that they encourage their students to form positive relationships with their peers $(M=4.44)$. The participants tended to agree that they teach their students to tell how they feel $(M=4.12)$ and tend to agree that they do witness caring behavior of their students in the classroom $(M=3.84)$. The participants were between neutral and disagree with engaging their students in community service activities $(M=2.84)$ to enhance caring. Our results suggest that teachers engage in some practices such as setting expectations and monitoring behaviors in ways that are aligned with increasing students' levels of caring.

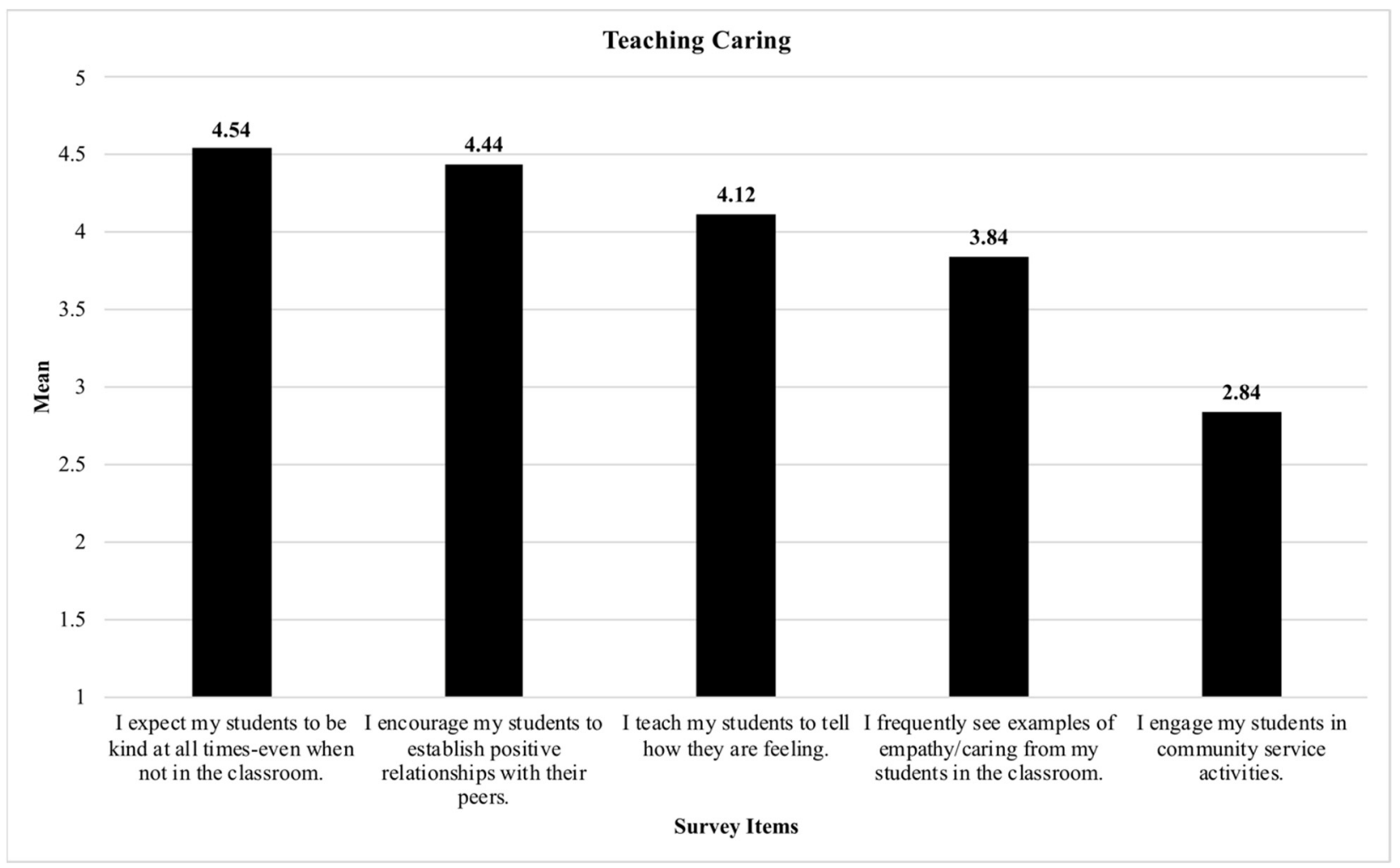

Figure 3. Perceptions and Practices for Teaching Caring

We next examined the focus of caring the participants shared in their free response narratives to our item, asking the teachers to share the facet of caring they would teach if they had more time (see Figure 4). Over half of the participants indicated that they would focus on teaching the students to care for themselves. About one-quarter of the participants indicated they would focus on caring for others, and the remaining participants indicated that they would focus on teaching the students to care for all. Thus, the primary focus for teaching caring was on caring for self. 


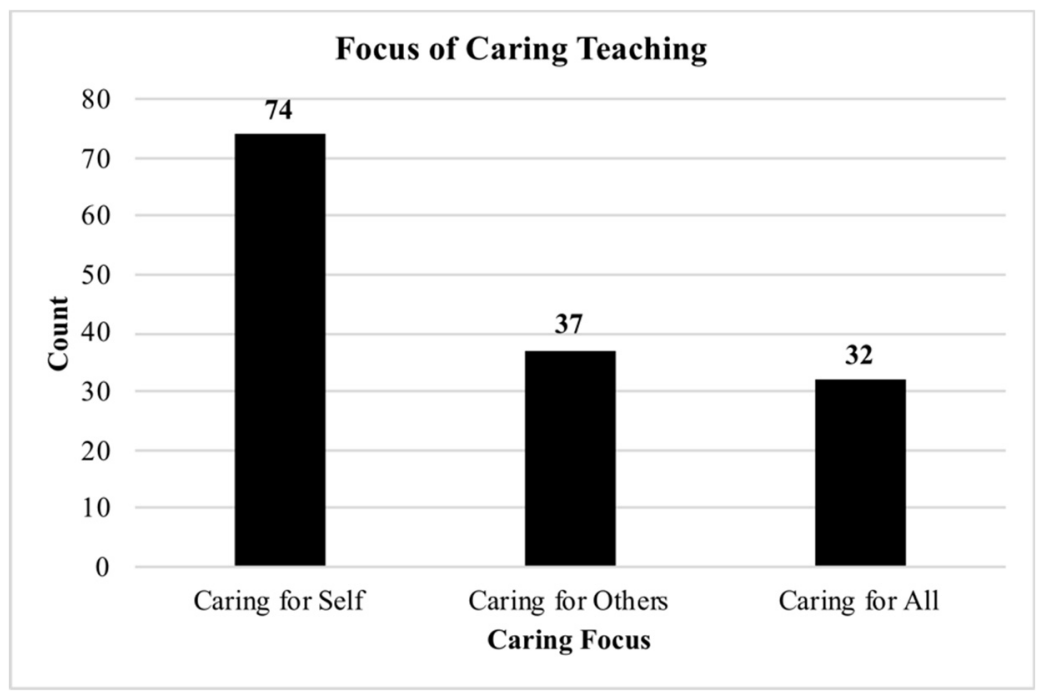

Figure 4. Focus of the Caring Taught if the Participants Had More Time to Teaching Caring

In Table 4, we provide representative responses aligned with the facet of caring that the participants wrote in their narratives. The responses to caring for self was similar to the representative response as the participants tended to focus on teaching for character development and self-esteem. In caring for others, the participants tended to focus on being kind to others and working well with others. The participants that focused on caring for all shared in their narratives the desire to teach citizenship and other social skills. Overall, the participants shared ideas in their responses that were achievable and reasonable, indicating that the teachers had likely reflected on their role and responsibility for teaching caring and the content and instruction they would use to assure the students achieved their learning goals.

Table 4. Coded Representative Responses to Caring Content

\begin{tabular}{ll}
\hline \multicolumn{1}{c}{ Facet of Caring } & \multicolumn{1}{c}{ Representative Response } \\
\hline Caring for Self & $\begin{array}{l}\text { Character development and self-motivation/self-esteem connected to doing things with and for others } \\
\text { to share and learn real life skills and hobbies. } \\
\text { Caring for Others }\end{array}$ \\
Haring for All & Appropriate social skills and citizenship (sportsmanship, kindness, friendship). I \\
& would also like to have more time to just do fun activities/games just for fun. \\
\hline
\end{tabular}

Along with the focus of the caring being taught, we also examined the participants' instructional method used when teaching for caring and curiosity (see Figure 5). We found that the instructional methods shifted based on the context of teaching caring, indicating that the participants would likely approach teaching caring in general differently than when teaching to increase students' empathetic curiosity. For example, when teaching for caring the most frequently communicated instructional method for was the use of dialog, followed by role modeling. However, when teaching for curiosity, the instructional methods also included a high use of dialog but there was a notable shift to an increased emphasis on independent exploration, with very few teachers indicating that they used role modeling for instruction. Similarly, when the focus was caring, few teachers engaged in the use of independent exploration and an instructional method. 


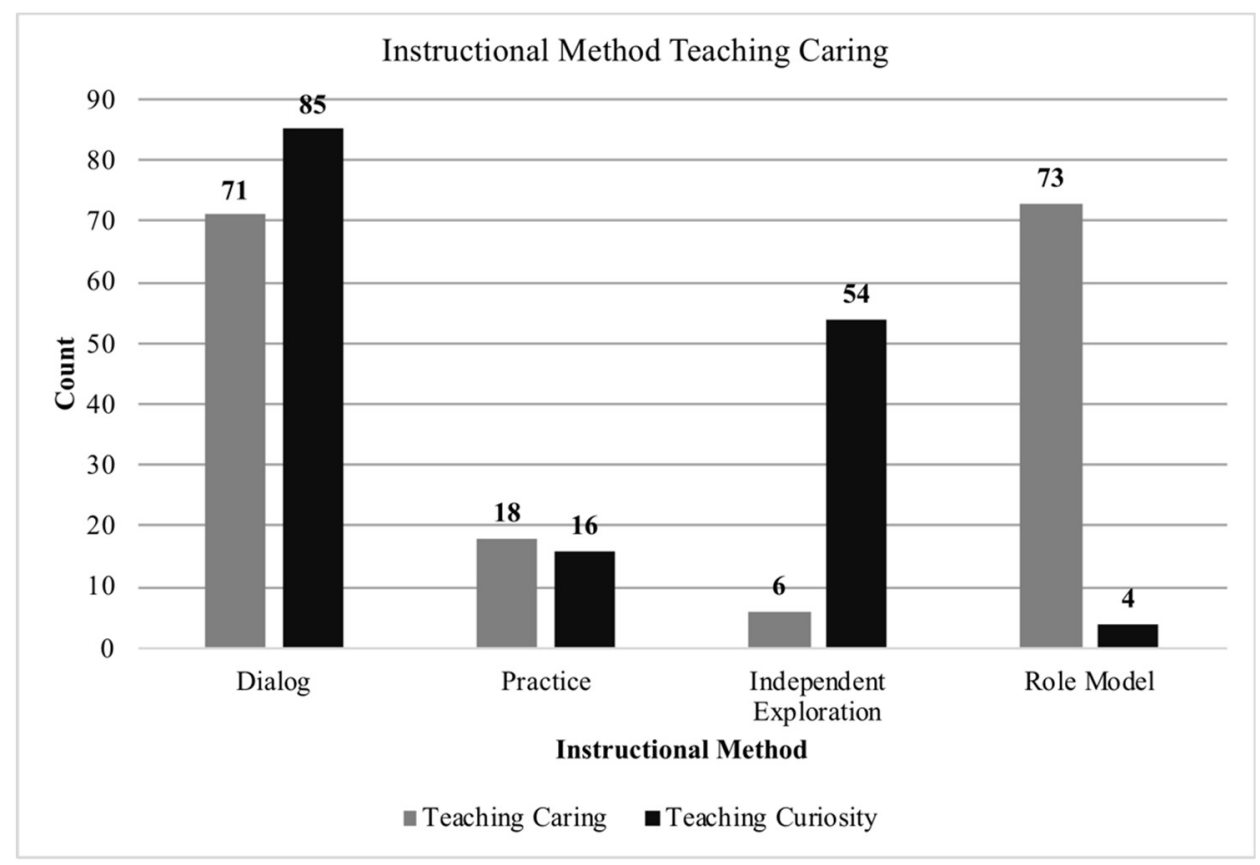

Figure 5. The Instructional Method the Participants Indicated They Would Use to Teach Caring When the Focus is Teaching Curiosity or the Focus is Teaching Caring

In Table 5, we share some representative responses that we coded to be aligned with the different instructional methods that the participants indicated that they would use to teach caring. The responses suggest that some efforts to teach students to be caring may be taking place as part of a formal curriculum or part of a more implicit curriculum. The responses also reflect active teacher engagement and an assumption by the teachers to be responsible for teaching students to be caring.

Table 5. Coded Representative Responses of the Instructional Methods for Teaching Caring

\begin{tabular}{ll}
\hline \multicolumn{1}{c}{ Instructional Method } & \multicolumn{1}{c}{ Representative Response } \\
\hline Dialog & Asking open ended questions that create deep thought after a lesson or story. \\
Practice & We spend a lot of class time on "life skills." Part of those skills include learning how react to situations and \\
& emotions of others. \\
Independent Exploration & Teaching them to know, accept, and understand their own feelings. This allows them understand how \\
& someone else might be feeling. \\
Role Model & I start by being the example, and when situations occur, I use them as teaching opportunities. \\
\hline
\end{tabular}

\subsection{Teaching Curiosity}

Our fourth guiding research questions asked, What practices do teachers use to teach their students to be curious? To answer this question, we examined the coded responses to our qualitative item asking the teachers to share how they teach curiosity. We coded the responses in alignment to facets of curiosity posited by Kashdan and colleagues (2018). To answer our question we also examined the teachers' responses to the curiosity teaching selected response items.

In Figure 6, we share the frequency of the coded content facet of curiosity communicated as being taught and the instructional method to teach the content. Our analysis revealed the practice the teachers tended to use with the highest frequency was social curiosity, such as setting up situations for students to interact with others. It is important to note that social curiosity has some overlap with empathetic curiosity. Joyous exploration and deprivation sensitivity were the next most frequent instructional methods conveyed by the teachers. In alignment with joyous exploration, the teachers indicated that they created opportunities for students to engage in inquiry and explore to answer questions that the students generated themselves. When the instructional content was aligned with deprivation sensitivity, the teachers created situations in which students were motivated to answer a question or solve 
a problem due to a lack of knowledge and an eagerness to fill the gaps in their knowledge. Few teachers responded with emphases on stress tolerance and thrill-seeking, which indicates that the teachers are not using stressful situations to teach curiosity and avoid creating thrill seeking conditions for foster students' curiosity development.

Our comparison between the instructional content and the teaching methods when teaching curiosity revealed some consistencies and some variations. We found that the teachers tended to avoid focusing on thrill-seeking for both content and instructional methods. A comparison of the teachers' focus on curiosity content and their curiosity instructional method revealed increases in emphasis on joyous exploration and deprivation sensitivity and decreases in social curiosity and stress tolerance. Our results suggest the facet of curiosity content that teachers tend to teach is not aligned with their instruction methods for teaching curiosity.

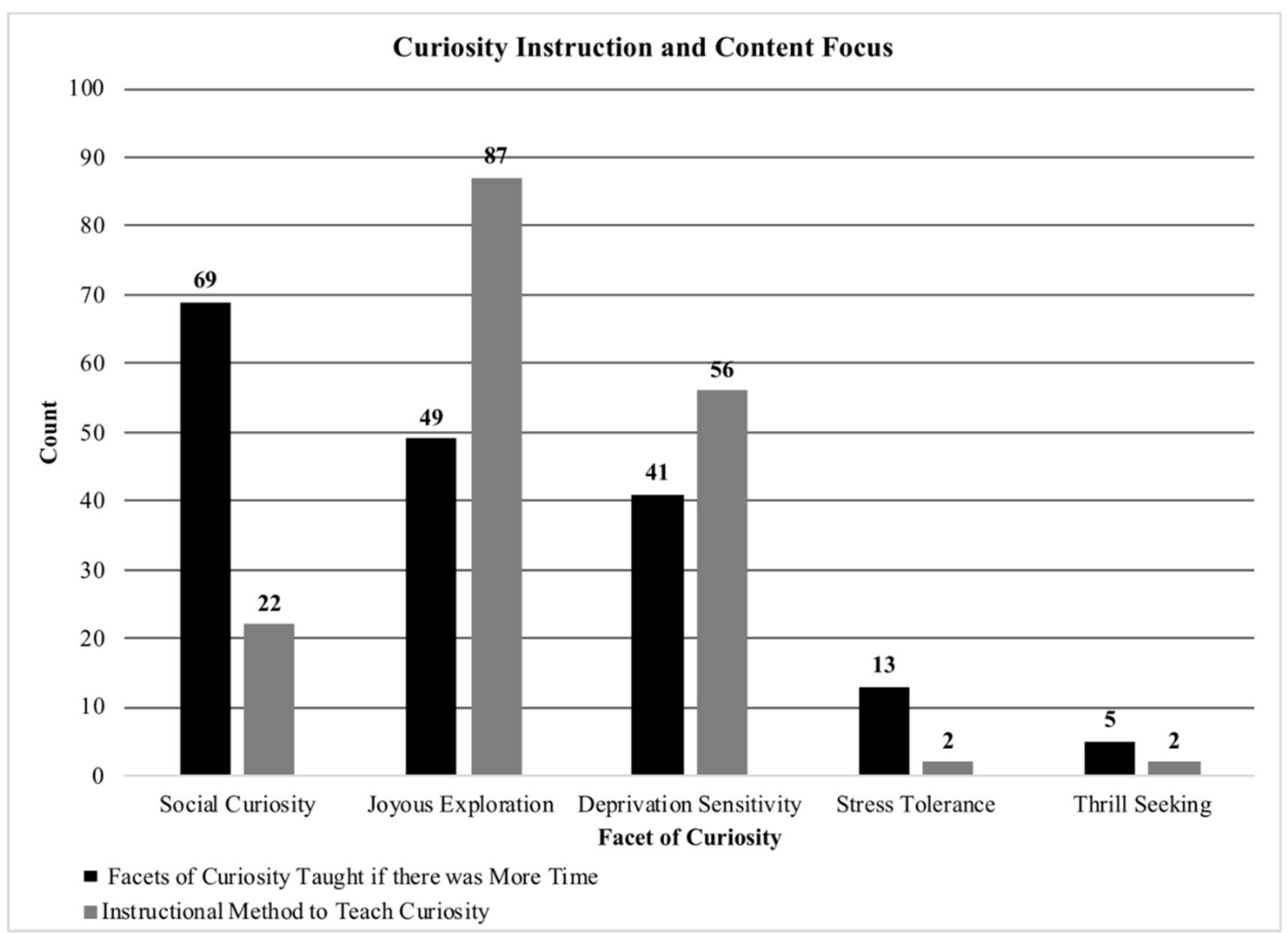

Figure 6. Frequency of the Codes of the Participants' References to the Facets of Curiosity in Their Free Responses to Our Item for Teaching Curiosity

In Table 6, we present some representative responses of the participants to our qualitative item, asking them about how they would teach curiosity. Our analysis of the responses revealed rather broad answers with little details or specifics about the instructional content. Also, we found that the participants' responses lacked details of integrating curiosity content with content from the general curriculum.

Table 6. Coded Representative Responses to Content Emphasized When Teaching Curiosity

\begin{tabular}{ll}
\hline \multicolumn{1}{c}{ Facet of Curiosity } & \multicolumn{1}{c}{ Representative Response } \\
\hline Deprivation Sensitivity & $\begin{array}{l}\text { I encourage my students to become more curious by allowing them to research specific topics and then report } \\
\text { to the entire class. }\end{array}$ \\
Social Curiosity & $\begin{array}{l}\text { Allow them time to explore their world and interact with others. } \\
\text { I expose them to various books and info. We also have centers where they are able to converse and apply what } \\
\text { they learn in class. }\end{array}$ \\
Stress Tolerance & Social skills with curriculum and anxiety reduction. \\
Thrill Seeking & Respect their ideas! Encourage them to explore and think outside of the box. Allow students to use their voice. \\
\hline
\end{tabular}


In Table 7, we present representative answers of the instructional approach the participants use to teach curiosity aligned with the five facets of curiosity. Similar to the curiosity content, the responses for how the participants would teach curiosity were rather vague and lacked details. Thus, while the participants indicate that they would apply various instructional methods to teach curiosity, they may have had limited ideas of how the instruction would take place, or perceive that they are already teaching their students to be curious, yet may lack assessments to determine the outcome.

Table 7. Coded Representative Responses to Instructional Method for Teaching Curiosity

\begin{tabular}{|c|c|}
\hline Facet of Curiosity & Representative Response \\
\hline Deprivation Sensitivity & $\begin{array}{l}\text { I encourage them to research topics they know nothing about and give them projects that open their eyes to } \\
\text { people, places, and things they aren't usually exposed to. }\end{array}$ \\
\hline Social Curiosity & To contemplate their individual actions and the impact they have on others \\
\hline Joyous Exploration & $\begin{array}{l}\text { By asking questions about what they think of an idea or subject. What do they know and what do they want to } \\
\text { know questions. }\end{array}$ \\
\hline Stress Tolerance & Life skills, real world situations. \\
\hline Thrill Seeking & The love of reading and where books can take you. \\
\hline
\end{tabular}

In Figure 7, we present the mean responses to our selected response items related to teaching curiosity. We found that the teachers tended to agree to strongly agree $(M=4.34)$ that they encourage their students to think of different ways to solve problems. The participants were slightly above agree $(M=4.20)$ to the statement that they encourage their students to ask meaningful questions. The teachers indicated that they agreed $(M=4.05)$ that they teach their students new strategies. The participants were near neutral $(M=3.15)$ to having their students conduct experiments. The participants were also near neutral $(M=2.92)$ to having time each week for their students to explore items of their choice. We interpret the results to indicate that the teachers tended to apply instructional approaches that may be effective for increasing students' levels of curiosity and the use of some approaches (i.e., thinking about different ways to solve problems) are fairly consistently applied by the participants.

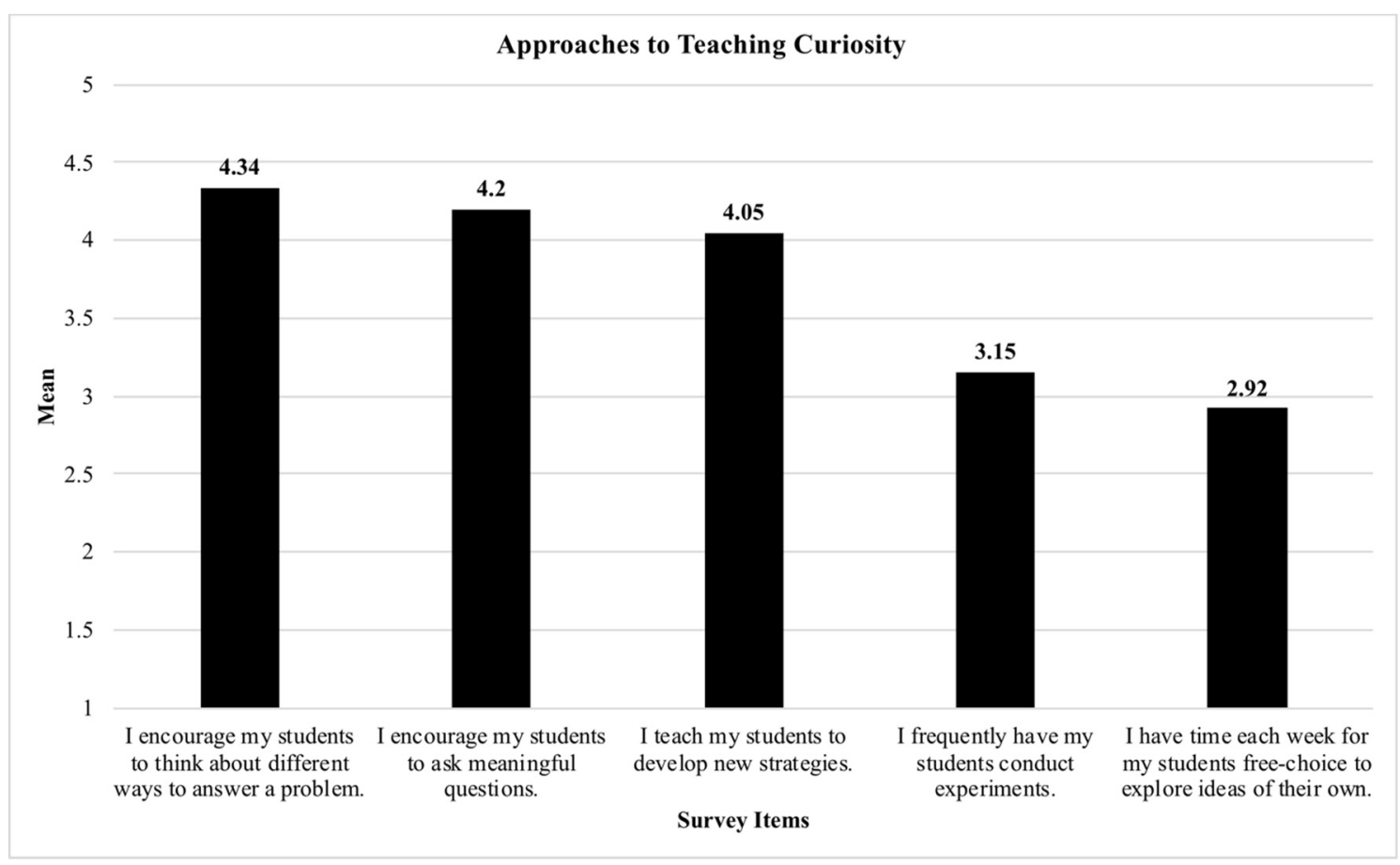

Figure 7. Mean Responses of Our Participants to Our Teaching Curiosity Selected Response Items 


\subsection{Relationship between Caring and Curiosity}

Our fifth guiding research question asked, What is the relationship between the teachers' perceptions and practices for caring and curiosity teaching and learning? To answer this question, we examined the correlations between and among our composite scores (see Table 8). Our correlational analysis revealed the composite scores for our perceptions and practices for teaching and learning curiosity and caring were all significantly positively correlated (see Table 8). The weakest correlation was between teaching caring and learning curiosity $(r=.15, p<.05)$. We interpret the correlation to suggest that teachers' perceptions and practices for teaching caring, were not necessarily aligned with their perceptions of students learning curiosity. The strongest correlation was between teaching curiosity and teaching caring $(r=.44, p<.01)$ which indicates that there is an alignment between how teachers tend to perceive and engage in the teaching practice of caring and curiosity. The other relationships indicate some alignment between the teachers' perceptions and practices for teaching and learning caring and curiosity.

Table 8. Correlations of Perceptions and Practices of Teaching and Learning Caring and Curiosity

\begin{tabular}{cccc}
\hline & Learning Curiosity & Teaching Caring & \multicolumn{2}{c}{ Teaching Curiosity } \\
\hline Learning Caring & $.20^{* *}$ & $.23^{* *}$ & $.24^{* *}$ \\
Learning Curiosity & & $.15^{*}$ & $.22^{* *}$ \\
Teaching Caring & & & $.44^{* *}$ \\
\hline
\end{tabular}

**. $p<0.01$ level, $* p<.05$ (2-tailed)

\subsection{Differences in Perceptions and Practices}

Our fifth guiding research questions asked, Are there differences in perceptions and practice based on the school type, location, or demographics? To answer this question, we examined the outcomes of our coding and the selected response items using our demographic data for group comparisons. Our analysis revealed no differences by age, years of experience, gender, degree earned, community location, type of school system, or school level. We did find differences in practices for teaching curiosity by ethnicity $[F(2,173)=4.55, p=.012]$ with the Tukey post-hoc revealing pairwise difference between Native Americans substantially greater and Caucasians. We also found differences in perceptions about students learning to be caring by percentage of students eligible for free and reduced lunch in the school $[F(4,131)=2.43, p<.05]$ with the Tukey post-hoc revealing teachers in schools with $25-50 \%$ eligible students having significantly lower perceptions of students learning to be caring than teachers working in schools where there were more than $75 \%$ of students were eligible for free and reduced lunch. Interpreted, teachers in schools with moderate levels of students eligible for free and reduced lunch schools held lower perceptions of students learning to be caring than teachers in schools with higher levels of students eligible for free and reduced lunch schools.

\section{Discussion and Implications}

The goal of our research was to determine the extent to which K-12 teachers perceive the teaching and learning of caring and curiosity and assess their caring and curiosity teaching practices and content choices. The motivation for our research is the need for students to gain empathetic curiosity which requires students to be both caring and curious about others. We maintain that students need to be taught how to be empathetically curious, and teachers play a critical role in helping students develop into caring and curious individuals. Our research provides insight into how teachers are teaching students to be curious and caring and their perceptions of students' development of caring and curiosity dispositions.

\subsection{Perceptions of Learning to be Caring}

Our results indicate that the teachers perceive that students can learn to be more caring, which is reflective of a growth mindset (Dweck, 2013, 2015). Thus, we speculate that the teachers embrace a growth mindset perspective when considering students' capacity to learn to be caring. In prior research, we found many post-secondary educators perceive that students cannot be taught to be caring and therefore tended to hold a fixed mindset perspective for students developing their dispositions (Nadelson \& Nadelson, 2019). Thus, the relatively high perceptions of the teachers in our present study that believe students can learn to be more caring may reflect a potential difference in perceptions of student disposition based on the developmental level of the students. Our data indicates that teachers are aware there are multiple influences on students caring development, including their teachers, as they shared the 
need to dedicate more time to teaching students to be respectful of others. The implications for our findings include the need to prepare teachers to assess and monitor the caring levels of their students, the influences on student caring development, and the potential barriers to students developing as caring individuals.

\subsection{Perceptions of Learning to Be Curious}

The participants held perceptions of students' learning of curiosity, similar to their perceptions of learning caring. Again, the teachers held a growth mindset perception of students learning to be curious and that students develop their curiosity over time. The teachers also perceived that students need support to develop their curiosity. The more tentative responses toward the influence of technology on curiosity, classroom interactions influencing curiosity, and the influence of education, suggests that the teachers may need to critically consider their instructional and content choices to align with their perceptions of how students develop curiosity. An examination of how teachers determine the curiosity learning needs of their students is a potentially fruitful direction for future research.

\subsection{Teaching Caring}

Our data indicate the participants engage in explicit teaching of caring through processes such as setting the tone for caring in their classrooms and engaging their students in talking about their feelings. The teachers also shared they engage in more implicit teaching actives such as monitoring the caring levels of their students and observation of students exhibiting caring behaviors. However, their methods of teaching were fairly vague and lacked specific interventions. Teacher implicit and explicit engagement in teaching students to be caring suggests that there is a need to prepare teachers to teach caring, which may need to be formally integrated into preservice preparation curricula or inservice professional development offerings. The focus on caring for self in the teaching of caring on reinforces the need to prepare teachers to effectively teach their students how to care for themselves, such as making healthy choices. In addition, the constrained focus on caring for others indicates that teachers may need to be prepared to teach their students to be empathetic. The shift in the instructional methods that the teachers indicated that they used to teach caring suggests a need to prepare teachers with a range of methods to teach caring and the ability to strategically integrate different approaches to align caring instruction with the appropriate context.

\subsection{Teaching Curiosity}

Our participants indicate that they take a variety of approaches to teach their students to be more curious. Yet, we did find a disconnect between the curiosity content focus and the instructional methods used to teach curiosity. The lack of alignment between the content focus and instructional methods for teaching curiosity suggests that teachers may not be effectively prepared to teach their students how to be curious. The lack of preparation to teach curiosity may be due to a lack of exposure to evidence-based practices for teaching students to be curious. The potential lack of formal preparation to teach students to be curious is also evident in the dearth of details provided by the teachers in their responses to our item asking them to share how they teach their students to be more curious. Given the data, we speculate that teachers may not be intentionally and consistently teaching their students to be curious. Thus, there is a need for additional research on teacher motivation and instructional choices for teaching their students to be curious and the duration or integration of their curiosity instruction with other content.

\subsection{Relationship between Caring and Curiosity}

The relationships among the measures of caring and curiosity perceptions of learning, perception of teaching, and teaching practices indicate that teachers tend to perceive the teaching and learning of dispositions consistently. The implications for our findings have the potential for holistically examining the caring and curiosity content as essential dispositions. We speculate that teachers may perceive teaching and learning of positive dispositions collectively and therefore are consistent in their consideration of teaching and learning dispositions, including caring and curiosity. In future research, we plan to examine teachers' perceptions of teaching and learning a wider range of dispositions for trends of consistency and variation.

Returning to the intersection of caring and curiosity, we speculate a focus on empathetic curiosity in the preparation of teachers to promote these dispositions could enhance teacher perceptions and practices for teaching both caring and curiosity. We posit that teachers would be better equipped to engage in conflict resolution, teach aligned with cultural competency, and support educational equity if they gain awareness of and are prepared to teach empathetic curiosity. Thus, teachers need to not only understand the importance of teaching their students to be both curious and caring but use evidence-based strategies to prepare their students to effectively work others. Examining how to best prepare teachers to support their students' development of empathetic curiosity is a potentially fruitful direction for future research. 


\section{Limitations and Directions for Future Research}

The first limitation of our research is the participants were all drawn from the same region in the southern United States. It is possible that teachers from different communities, regions, and cultures may have different perceptions and practices for teaching and learning caring and curiosity. However, our data revealed few differences based on individual differences and variations in school or community characteristics. Future research should explore the perceptions and practices of teacher from different populations and compare the outcomes for consistency and variation.

The second limitation of our research was the nature of our data collection. We gathered the data with a anonymous survey, distributed on-line, which limited our ability to follow-up with additional questions. Due to the exploratory nature of our research, we were seeking to establish a baseline for teachers' perceptions and practices in teaching and learning caring and curiosity, thus our choice for a cross-sectional study using the survey. However, moving forward we plan to conduct interviews of educators that are actively engaged in teaching caring and curiosity to gain greater in-depth understanding of teachers' perceptions and practices and their justifications for their thoughts, motivations, and instructional choices.

\section{Conclusion}

The increasing need to develop productive citizens who can flourish in a culturally diverse world requires the ability to gain a deeper appreciation for other perspectives. In order to develop the necessary insight and understanding of others to work together requires a deep level of both curiosity and caring. Motivated by the importance of being able to work with others, we explored teachers' perceptions and practices associated with teaching and learning caring and curiosity. Our findings indicate the teachers do value both caring and curiosity. They work to develop higher levels of both. However, many seem to lack evidence-based interventions to assist in the building of strong character traits in their pupils. Our research provides a foundation for understanding the situation and illuminated multiple additional lines of research. We hope others will join us as we continue to explore teaching and learning caring and curiosity for the development of empathetic curiosity.

\section{References}

Baumgarten, E. (2001). Curiosity as a moral virtue. International Journal of Applied Philosophy, 15(2), 169-184. https://doi.org/10.5840/ijap200115215

Ben-Peretz, M., Mendelson, N., \& Kron, F. W. (2003). How teachers in different educational contexts view their roles. Teaching and Teacher Education, 19(2), 277-290. https://doi.org/10.1016/S0742-051X(02)00100-2

Bertram, T., \& Pascal, C. (2002). What counts in early learning. In O. N. Saracho \& B. Spodek (Eds.), Contemporary perspectives in early childhood curriculum, (pp. 241-256). Greenwich, CT: Information Age.

Binson, B. (2009). Curiosity-based learning (CBL) program. US-China Education Review, 6(12), 13-22.

Blackwell, J. (1999). Project caring. New addition to the curriculum and the next millennium priority list. Childhood Education, 75(5), 304E.

Borowiec, J. B., \& Langerock, N. L. (2002). Creating empathetic spaces. Curriculum and Teaching Dialogue, 4(2), 79-87.

Brown, B. (2015). Daring greatly: How the courage to be vulnerable transforms the way we live, love, parent, and lead. New York, NY: Penguin.

Carr, M., \& Claxton, G. (2002). Tracking the development of learning dispositions. Assessment in Education: Principles, Policy \& Practice, 9(1), 9-37. https://doi.org/10.1080/09695940220119148

Cloninger, K. (2008). Giving beyond care: An exploration of love in the classroom. Curriculum and Teaching Dialogue, 10(1\&2), 193-211.

Cotton, K. (1992). Developing empathy in children and youth. Portland, OR: Northwest Regional Educational Laboratory.

Cronin, M. E. (1996). Life skills curricula for students with learning disabilities: A review of the literature. Journal of Learning Disabilities, 29(1), 53-68. https://doi.org/10.1177/002221949602900108

Deming, D. (2009). Early childhood intervention and life-cycle skill development: Evidence from Head Start. 
American Economic Journal: Applied Economics, 1(3), 111-134. https://doi.org/10.1257/app.1.3.111

Derman-Sparks, L. (1993). Empowering children to create a caring culture in a world of differences. Childhood Education, 70(2), 66-71. https://doi.org/10.1080/00094056.1993.10520994

DeRoche, E. F., \& Williams, M. M. (2001). Educating hearts and minds: A comprehensive character education framework (2nd ed.). Thousand Oaks, CA: Corwin Press.

Du, K., Buchanan, M., Hayhurst, J., \& Ruffman, T. (2019). Parent talk about the wellbeing of others in disciplinary situations relates to younger children's empathy. New Zealand Journal of Psychology, 48(1), 106.

Durlak, J. A., Weissberg, R. P., Dymnicki, A. B., Taylor, R. D., \& Schellinger, K. B. (2011). The impact of enhancing students' social and emotional learning: A meta analysis of school - based universal interventions. Child Development, 82(1), 405-432. https://doi.org/10.1111/j.1467-8624.2010.01564.x

Dweck, C. S. (2013). Mindset: The psychology of success. New York, NY: Ballantine Books.

Dweck, C. (2015). Carol Dweck revisits the growth mindset. Education Week, 35(5), 20-24.

Dyjur, P., \& Li, Q. (2010). A study of designing an inquiry-based unit in mathematics and science. Journal on School Educational Technology, 5(4), 35-43. https://doi.org/10.26634/jsch.5.4.1151

EAST Initiative (2018). Education accelerated by service \& technology. Retrieved from https://www.eastinitiative.org/

Engel, S. (2011). Children's need to know: Curiosity in schools. Harvard Educational Review, 81(4), 625-645. https://doi.org/10.17763/haer.81.4.h054131316473115

Espelage, D. L., Mebane, S. E., \& Adams, R. S. (2004). Empathy, caring, and bullying: Toward an understanding of complex associations. In D. L. Espelage \& S. M. Swearer (Eds.), Bullying in American schools: A social-ecological perspective on prevention and intervention (pp. 37-61). Mahwah, NJ: Erlbaum. https://doi.org/10.4324/9781410609700

Foss, S. (2014). Visual, critical, and scientific thinking dispositions in a 3rd grade science classroom (Unpublished doctoral dissertation). Walden University, Minneapolis, MN.

Gerace, A., Day, A., Casey, S., \& Mohr, P. (2015). Perspective taking and empathy: Does having similar past experience to another person make it easier to take their perspective? Journal of Relationships Research, 6, 1-14. https://doi.org/10.1017/jrr.2015.6

Greenberg, M. T., Weissberg, R. P., O'brien, M. U., Zins, J. E., Fredericks, L., Resnik, H., \& Elias, M. J. (2003). Enhancing school-based prevention and youth development through coordinated social, emotional, and academic learning. American Psychologist, 58(6-7), 466. https://doi.org/10.1037/0003-066X.58.6-7.466

Gurning, B., \& Siregar, A. (2017). The effect of teaching strategies and curiosity on students' achievement in reading comprehension. English Language Teaching, 10(11), 191-198. https://doi.org/10.5539/elt.v10n11p191

Henson, R. K. (2001). Perceived responsibility of prospective teachers for the moral development of their students. Professional Educator, 23(2), 47-53.

Hyson, M., \& Taylor, J. L. (2011). Caring about caring: What adults can do to promote. Young Children, 66(4), 74-83.

Johnson, J. (2012). Education: A citizens' solutions guide. Brooklyn, NY: Public Agenda.

Jones, S. M., Bailey, R., \& Jacob, R. (2014). Social-emotional learning is essential to classroom management. Phi Delta Kappan, 96(2), 19-24. https://doi.org/10.1177/0031721714553405

Kashdan, T. B., Stiksma, M. C., Disabato, D. J., McKnight, P. E., Bekier, J., Kaji, J., \& Lazarus, R. (2018). The five-dimensional curiosity scale: Capturing the bandwidth of curiosity and identifying four unique subgroups of curious people. Journal of Research in Personality, 73, 130-149. https://doi.org/10.1016/j.jrp.2017.11.011

Kasl, E., \& Yorks, L. (2016). Do I really know you? Do you really know me? Empathy amid diversity in differing learning contexts. Adult Education Quarterly, 66(1), 3-20. https://doi.org/10.1177/0741713615606965

Katz, L. G. (1977). Dispositions: Definitions and implications. In L.G. Katz (Ed.), Talks with teachers: Reflections on early childhood education (pp. 51-69). Washington, DC: NAEYC.

Katz, L. G. (1993). Dispositions: Definitions and implications for early childhood practices. Perspectives from ERIC/EECE: A monograph series. Urban, IL: ERIC Clearinghouse on EECE. 
Kim, K., Harris, C. J., \& Pham, L. (2018). How character education impacts teachers. International Journal of Multidisciplinary Perspectives in Higher Education, 3(1), 45-67. https://doi.org/10.32674/jimphe.v3i1.632

Knodt, J. S. (2009). Cultivating curious minds: teaching for innovation through open-inquiry learning. Teacher Librarian, 37(1), 15-22.

Kohn, A. (2000). The case against standardized testing. Portsmouth, NH: Heinemann.

Lindholm, M. (2018). Promoting curiosity? Science \& Education, 27(9-10), 987-1002. https://doi.org/10.1007/s11191-018-0015-7

Lindsey, A., King, E., Hebl, M., \& Levine, N. (2015). The impact of method, motivation, and empathy on diversity training effectiveness. Journal of Business and Psychology, 30(3), 605-617. https://doi.org/10.1007/s10869-014-9384-3

Loewenstein, G. (1994). The psychology of curiosity: A review and reinterpretation. Psychological Bulletin, 116(1), 75-98. https://doi.org/10.1037/0033-2909.116.1.75

Louis, K. S., Murphy, J., \& Smylie, M. (2016). Caring leadership in schools: Findings from exploratory analyses. Educational Administration Quarterly, 52(2), 310-348. https://doi.org/10.1177/0013161X15627678

Luckey, K. L., \& Nadelson, L. S. (2011). Developing a life skills evaluation tool for assessing children ages 9-12. Journal of Youth Development, 6(1), 108-130. https://doi.org/10.5195/JYD.2011.202

McDermott, D. (2003). Building better human connections parenting/caring education for children and teens in school. Childhood Education, 80(2), 71-75. https://doi.org/10.1080/00094056.2004.10521260

McDermott, D. (2014). Children, parents and teachers learning how to care more effectively. Haiti Perspectives, 2(4), 43-47.

Mesurado, B., \& Richaud, M. C. (2017). The relationship between parental variables, empathy and prosocial-flow with prosocial behavior toward strangers, friends, and family. Journal of Happiness Studies, 18(3), 843-860. https://doi.org/10.1007/s10902-016-9748-7

Nadelson, S. G., \& Nadelson, L. S. (2019). Connecting critical thinking, caring, and curiosity in nurse education: Exploring the beliefs and practices of nurse educators. Journal of Nursing Education and Practice, 9(8), e-version first. https://doi.org/10.5430/jnep.v9n8p1

Narinasamy, I., \& Logeswaran, A. K. (2015). Teacher as moral model--are we caring enough? World Journal of Education, 5(6), 1-13. https://doi.org/10.5430/wje.v5n6p1

Neuman, S. B., \& K. Roskos. (2005). Whatever happened to developmentally appropriate practice in early literacy? Young Children, 60(4), 22-26.

Noddings, N. (2005). The challenge to care in schools (2nd ed.). New York, NY: Teachers College Press.

Orkin, W. (1996). Improving student life skills through classroom intervention and integrated learning (Unpublished master's thesis). Saint Xavier University, Chicago, IL.

Park, N., \& Peterson, C. (2009). Character strengths: Research and practice. Journal of College and Character, 10(4), 1-10. https://doi.org/10.2202/1940-1639.1042

Patrick, B. C., Hisley, J., \& Kempler, T. (2000). "What's everybody so excited about?": The effects of teacher enthusiasm on student intrinsic motivation and vitality. The Journal of Experimental Education, 68(3), 217-236. https://doi.org/10.1080/00220970009600093

Phillips, R. (2015). Curiosity: Care, virtue and pleasure in uncovering the new. Theory, Culture \& Society, 32(3), 149-161. https://doi.org/10.1177/0263276414565718

Phillips, R. (2016). Curious about others: Relational and empathetic curiosity for diverse societies. New Formations, 88, 123-142. https://doi.org/10.3898/NEWF.88.02.2016

Scott, K. E., \& Graham, J. A. (2015). Service-learning: Implications for empathy and community engagement in elementary school children. Journal of Experiential Education, 38(4), 354-372. https://doi.org/10.1177/1053825915592889

Shum, S. B., \& Crick, R. D. (2012, April). Learning dispositions and transferable competencies: pedagogy, modelling and learning analytics. In Proceedings of the 2nd international conference on learning analytics and knowledge (pp. 92-101). ACM. https://doi.org/10.1145/2330601.2330629 
Smith, E. R., \& Gill Lopez, P. (2016). Collaboration for a curriculum of caring: The zeitgeist is right. Psychology in the Schools, 53(3), 270-285. https://doi.org/10.1002/pits.21898

Smith, R. L., Hurst, J., \& Skarbek, D. (Eds.). (2005). The passion of teaching: Dispositions in the schools. Lanhan, Maryland: Scarecroweducation.

Tomita, F. (1997). What are parents' perceptions of professional in teaching? Japanese and English parents' expectations and satisfactions. Paper presented at the British Educational Research Association Annual Conference, University of York.

Tuff, L. (2009). Teacher perception of character education (Unpublished master's thesis). University of Lethbridge, Lethbridge, AB, Canada.

Wagers, K. B., \& Kiel, E. J. (2019). The influence of parenting and temperament on empathy development in toddlers. Journal of Family Psychology, 33(4), 391. https://doi.org/10.1037/fam0000505

Wentzel, K. R. (1997). Student motivation in middle school: The role of perceived pedagogical caring. Journal of Educational Psychology, 89(3), 411-419. https://doi.org/10.1037/0022-0663.89.3.411

Wheeler, E. (2005). Kindness in a curriculum for peace: beyond "random acts". Childhood Education, 81(5), 292I-292M.

Zion, M., \& Slezak, M. (2005). It takes two to tango: In dynamic inquiry, the self-directed student acts in association with the facilitating teacher. Teaching and Teacher Education, 21(7), 875-894. https://doi.org/10.1016/j.tate.2005.05.016 